\title{
IMPLEMENTASI TEORI SERVQUAL PADA LAYANAN AKADEMIK SATU PINTU
}

\author{
Umar Reza Saputra', Ismiyati Suwono², Mar'atus Sholikah ${ }^{3 *}$ \\ ${ }^{I}$ Fakultas Ilmu Sosial dan Ilmu Politik, Universitas Diponegoro, Indonesia \\ ${ }^{2}$ Fakultas Ekonomi, Universitas Negeri Semarang, Indonesia \\ ${ }^{3}$ Fakultas Ekonomi, Universitas Negeri Yogyakarta, Indonesia \\ umarreza@students.undip.ac.id ${ }^{1}$, ismiyati@mail.unnes.ac.id ${ }^{2}$, maratussholikah.2019@student.uny.ac.id ${ }^{3}$ \\ *Corresponding author
}

\begin{abstract}
Abstrak: Implementasi Teori SERVQUAL pada Layanan Akademik Satu Pintu. Dalam rangka meningkatkan kualitas pelayanan akademik, FE UNNES memperbarui pelayanan satu pintu dengan menambahkan bagian front office. Tugas front office yaitu memberikan pelayanan bagi mahasiswa terkait prosedur pengurusan surat menyurat melalui sistem surat dinas (SIRADI), layanan legalisir, layanan cetak KRS dan KHS. Untuk itu, penelitian ini bertujuan untuk menganalisis sebagai penambahan bagian baru yang melayani akademik mahasiswa pada Bagian Tata Usaha FE UNNES. Kualitatif deskriptif merupakan metode dan pendekatan penelitian yang digunakan. Untuk pengumpulan data, penelitian ini menggunakan observasi, wawancara, dan dokumentasi dengan analisis data dengan Teori Interaktif. Sumber data dalam penelitian ini adalah 27 informan. Analisis data dimulai dengan mengumpulkan data, mereduksi data, menyajikan data dan membuat kesimpulan. Hasil penelitian ini menunjukkan bahwa lima dimensi kualitas pelayanan meliputi dimensi tangible, reliability, responsiveness, assurance, dan empathy sudah baik. Namun, terdapat empat hambatan yang terjadi yaitu tempat pelayanan yang masih kurang memadai; fasilitas masih kurang lengkap dikarenakan tempat yang kurang luas; SIRADI yang terkadang error sehingga menghambat proses layanan; waktu pelayanan masih belum sesuai dengan waktu yang telah dijanjikan. Kesimpulan penelitian ini yaitu penyelenggaraan layanan akademik satu pintu sudah sesuai dengan teori SERVQUAL. Agar kepuasan mahasiswa meningkat, maka perguruan tinggi dapat meningkatkan kualitasnya dengan memperbaiki segala kendala-kendala yang dialami oleh mahasiswa.
\end{abstract}

Kata kunci: layanan akademik, front office, teori kualitas pelayanan, servqual, layanan satu pintu

\begin{abstract}
Implementation of SERVQUAL Theory on One-Stop Service Academic. To improve the quality of academic services, the Faculty of Economics of UNNES updated the one-door service by adding a front office. The front office duties are to provide services for students related to managing correspondence through the SIRADI system, legalization services, services about the printing of study result cards, and other academic services. Thus, this research aims to analyze the optimization of one-door educational services carried out by the Front Office of the Faculty of Economics, Universitas Negeri Semarang. This study used descriptive research methods with qualitative approaches-data collection techniques in observations, interviews, and documentation with data analysts with Interactive Theory. The data sources in this study were 27 informants. This study analyzes the data analysis through data collection, data reduction, data presentation, and inference. The finding showed that five dimensions of servant quality include tangible, reliability, responsiveness, assurance, and empathy, are already promising. However, four obstacles occur: (1) the place of service that is still inadequate; (2) facilities that are still not complete due to the large area; (3) the SIRADI system that sometimes errors to impede the service process; (4) service time that is yet not following the promised time. This research concludes that the implementation of one-door academic services is following the theory of SERVQUAL. For increasing student satisfaction, universities can improve their quality by improving all the obstacles experienced by students.
\end{abstract}

Keyword: academic services, front office, service quality theory, one-stop service

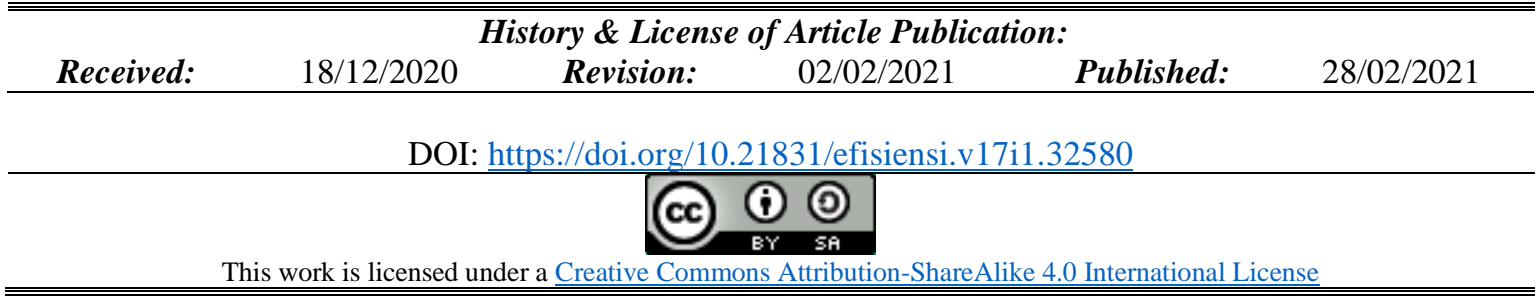




\section{PENDAHULUAN}

Pelayanan merupakan suatu yang wajib diberikan oleh instansi ataupun lembaga, termasuk di dunia pendidikan. Penyelenggara pendidikan juga mengupayakan untuk pelayanan terbaik untuk warga. Oleh karena itu, pimpinan lembaga pendidikan terus berupaya mengevaluasi dan mengatur strategi dan membuat kebijakan dalam peningkatan pelayanan yang diberikan. Dengan demikian, lembaga pendidikan dituntut agar dapat mengelola lembaga menjadi lebih profesional. Sejalan dengan Chrisyanti (2011) yang menyatakan bahwa penyedia pelayanan kantor adalah fungsi spesialisasi, yang memiliki keterampilan dan ilmu pengetahuan sendiri. Bila pelayanan kantor efektif, maka kerja sama penuh di antara manajer kantor dan manajer fungsi lainnya akan tercapai dengan baik.

Kemampuan pegawai yang sesuai bidang sangat penting bagi sebuah instansi untuk meningkatkan kinerja. Berkaitan dengan instansi pendidikan, pengelolaan administrasi sangat kompleks sehingga membutuhkan pegawai yang mumpuni untuk membantu dan memperlancar administrasi tersebut. Sesuai dengan hasil penelitian Arisandy (2015), kesesuaian bidang dan keterampilan kerja akan memudahkan sebuah instansi untuk mencapai tujuan organisasi, sebaliknya ketidaksesuaian bidang dan kurang keterampilan dapat menghambat tujuan organisasi. Salah satu tujuan sebuah instansi yaitu memberikan pelayanan yang memuaskan dan sesuai dengan kebutuhan pelanggan. Gie (2012) menerangkan bahwa pelayanan administrasi perkantoran merupakan salah satu pelayanan yang penting dalam sebuah instansi/lembaga.

Oleh karena itu, universitas merupakan salah satu lembaga yang turut memberikan pelayanan terbaiknya. Ciri pelayanan yang baik yaitu pelayanan mementingkan kepuasan pelanggan, memperhatikan kualitas layanan, mampu memberikan pelayanan secara efektif, memberikan kemudahan kepada pihak lain untuk memperoleh pelayanan tanpa adanya keinginan mendapatkan imbalan atau balas jasa serta dapat menerapkan standar kualitas pelayanan tinggi (Sholikah \& Harsono, 2020). Hal ini selaras dengan Sianipar (2018), karakteristik pelayanan yang baik hendaknya mampu melayani secara cepat dan tepat, artinya dalam melayani mahasiswa diharapkan pegawai dapat memberikan layanan sesuai dengan jadwal dan sesuai dengan standar serta keinginan mahasiswa selaku pelanggan lembaga pendidikan tinggi. Dengan demikian pelanggan akan merasa puas terhadap pelayanan yang diberikan. Hampir sama dengan Tjiptono (2017) yang menyatakan bahwa pelayanan menyiratkan pekerjaan yang dilakukan oleh pihak lain untuk membantu pihak tertentu. 
Standar pelayanan di perguruan tinggi ditetapkan seiring dengan meningkatnya peran perguruan tinggi dalam mendukung program pemerintah. Akan tetapi dalam pemberian layanan masih ditemukan beberapa permasalahan seperti keterlambatan dialami oleh mahasiswa dalam pengurusan surat misalnya surat izin observasi, maupun pengurusan lain. Suatu instansi dapat dikatakan telah profesional dalam memberikan pelayanan jika kualitas pelayanan yang diberikan memuaskan atau sesuai dengan harapan pelanggan (Ghofur, 2013). Pelayanan jasa merupakan sebuah pelayanan tidak berwujud yang diberikan oleh instansi kepada konsumen (mahasiswa). Pelayanan ini tidak dapat dilihat, akan tetapi dapat dirasakan manfaatnya oleh setiap konsumen (mahasiswa) yang menggunakan jasa tersebut.

Kualitas pelayanan menunjukkan tingkat kesempurnaan tingkat pelayanan dalam memenuhi kebutuhan dan tuntutan setiap mahasiswa. Hal serupa pernah diteliti oleh Ismiyati (2011) mengenai faktor daya tarik dan kinerja pelayanan menurut persepsi mahasiswa: studi FE UNNES, menyatakan bahwa kinerja pelayanan di lihat dari faktor keunggulan menunjukkan bahwa mahasiswa masih belum puas terhadap pelayanannya. Akan tetapi, apabila dilihat dari faktor promosi, lokasi, dan penampilan menunjukkan bahwa mahasiswa sudah cukup puas terhadap faktor-faktor yang mempengaruhi kinerja pelayanannya.

Fakultas Ekonomi UNNES mulai melakukan pembaruan sistem pelayanan pada tanggal 1 Februari 2019 yaitu dengan adanya bagian Front Office, bertujuan agar sistem pelayanan lebih terstruktur yang difokuskan kepada bagian tersebut serta mempermudah mahasiswa dalam memperoleh pelayanan. Pelayanan secara efektif dan efisien untuk memberikan kepuasan sesuai standar pelayanan terhadap mahasiswa merupakan faktor utama dilakukannya pembaruan tersebut. FE UNNES memiliki beberapa bagian atau bidang yang saling berhubungan dan merupakan kesatuan yang kuat satu sama lain.

Berdasarkan hasil angket sampel yang telah dilakukan oleh peneliti selama 5 hari kerja dari tanggal 18 Maret 2019 sampai dengan 22 Maret 2019, peneliti mendapatkan informasi bahwa pelayanan yang diberikan kepada mahasiswa FE UNNES masih ditemukan data kurang puas dari mahasiswa terhadap pelayanan yang telah dilakukan oleh Bagian Front Office Tata Usaha FE UNNES ditampilkan dalam Tabel 1.

Tabel 1. menunjukan jumlah pengguna layanan selama kurun waktu 5 hari kerja melalui bagian Front Office FE UNNES sejumlah 201 mahasiswa. Penyebaran angket kepuasan yang dilakukan bagian Front Office itu merupakan suatu pengukuran terhadap tingkat kepuasan pelayanan terhadap mahasiswa, sehingga pelayanan yang diberikan memiliki tingkat kepuasan yang diharapkan oleh mahasiswa. Kepuasan pengguna jasa mahasiswa menjadi salah satu ukuran dari keberhasilan lembaga pendidikan dalam 
Edisi Februari 2021, Volume 18, Nomor 1, ISSN 1412-1131, e-ISSN 2528-5750, Halaman 63-89

mengelola lembaga pendidikan dengan tetap memperhatikan mutu akademik sebagai produk jasa yang harus dicapai (Agustini, 2020; Mulyawan \& Sidharta, 2013).

Tabel 1. Trend Kepuasan Front Office FE UNNES

\begin{tabular}{cccccc}
\hline Kategori & Sangat Puas & Puas & Kurang Puas & Tidak Puas & Jumlah \\
\hline Hari 1 & 45 & 10 & 2 & 0 & 57 \\
Hari 2 & 29 & 13 & 1 & 0 & 43 \\
Hari 3 & 39 & 7 & 0 & 0 & 46 \\
Hari 4 & 12 & 1 & 1 & 0 & 14 \\
Hari 5 & 29 & 10 & 2 & 0 & 41 \\
\hline \multirow{2}{*}{ Jumlah } & 154 & 41 & 6 & 0 & 201 \\
& $(76,62 \%)$ & $(20,40 \%)$ & $(2,98 \%)$ & $(0 \%)$ & $(100 \%)$ \\
\hline
\end{tabular}

Hasil angket tersebut menjelaskan bahwa tingkat kepuasan pada pelayanan melalui Front Office dari 154 atau sekitar 76,62\% mahasiswa merasa sangat puas, 41 atau sekitar 20,40\% mahasiswa merasa puas, 6 mahasiswa atau sekitar 6,28\% mahasiswa merasa kurang puas dan tidak terdapat mahasiswa yang tidak puas atau sekitar $0 \%$. Berdasarkan kondisi tersebut serta dengan dukungan penelitian terdahulu yang berkaitan dengan kualitas pelayanan, maka dirasa perlu untuk melakukan penelitian tentang "Implementasi Teori SERVQUAL pada Layanan Akademik Satu Pintu".

Teori SERVQUAL atau service quality menurut Zeithaml \& Bitner (2000) merupakan salah satu metode yang digunakan oleh lembaga dalam rangka meningkatkan kualitas pelayanan. Teori ini mencakup pengembangan dan pemahaman mengenai kebutuhan layanan yang dirasakan pelanggan. Kualitas layanan sering diukur berdasarkan persepsi kualitas layanan diberikan oleh organisasi bersangkutan, selanjutnya dikomparasikan dengan organisasi lain dengan kualitas layanan yang sangat baik. Hasil analisis kesenjangan tersebut akan menjadi acuan untuk peningkatan kualitas layanan. Dimensi dalam kualitas pelayanan jasa menurut teori SERVQUAL terbagi dalam lima dimensi yaitu tangible, reliability, responsiveness, dan emphaty. Dengan demikian, penelitian ini mengkaji optimalisasi kualitas pelayanan dengan lima dimensi SERVQUAL yaitu keandalan, daya tanggap, bukti fisik, empati, serta jaminan. Ruang lingkup penelitian ini adalah optimalisasi kualitas pelayanan yang dilakukan oleh Front Office TU FE UNNES dengan pembaharuan pelayanan menggunakan layanan satu pintu.

\section{METODE}

Jenis penelitian ini merupakan penelitian kualitatif, yang bertujuan untuk mengkaji tentang optimalisasi pelayanan akademik di bagian Front Office Tata Usaha FE UNNES, 
dengan menggunakan beberapa indikator kualitas pelayanan SERVQUAL. Sumber data penelitian diperoleh melalui wawancara langsung kepada Dekan Fakultas Ekonomi UNNES, Wakil Dekan Bidang II, Kepala Tata Usaha, Kepala Bagian Akademik dan Kemahasiswaan, Staf Front Office, Magang PKL siswi SMK di bagian Front Office, Mahasiswa Fakultas Ekonomi per jurusan angkatan 2016-2018, dengan total informan 27 orang. Fokus dalam penelitian ini sesuai dengan tujuan penelitian yaitu optimalisasi layanan akademik di bagian Front Office Tata Usaha FE UNNES. Teknik yang digunakan dalam pengumpulan data meliputi observasi, wawancara dan dokumentasi. Wawancara yang digunakan dalam penelitian ini adalah terstruktur.

Teknik analisis yang digunakan untuk menganalisis data dalam penelitian ini adalah deskriptif kualitatif. Data yang dianalisis dalam penelitian dimulai dengan wawancara yang dilakukan secara face-to-face, karena media ini menjadi pilihan yang paling efektif untuk memperoleh informasi menjadi lebih jelas. Hal ini dikarenakan apabila terjadi missunderstanding, peneliti dapat mengkonfirmasi ulang pernyataan dari informan. Selama proses wawancara, wawancara direkam menggunakan aplikasi voice recorder. Proses wawancara berlangsung kurang lebih 30 menit. Instrumen wawancara yang digunakan berpedoman pada teori kualitas pelayanan SERVQUAL. Penggunaan instrumen wawancara ini dilakukan agar masalah yang ditanyakan fokus pada kualitas layanan. Selanjutnya, setelah data terkumpul yaitu berupa transkrip wawancara, dianalisis menggunakan teknik interaktif. Teknik ini akan menganalisis data dalam beberapa tahap yaitu mereduksi data, mempresentasikan data, memverifikasi data, dan terakhir menyajikannya menjadi kesimpulan (Miles \& Hubberman, 1994).

\section{HASIL DAN PEMBAHASAN}

\section{Hasil Penelitian}

\section{Dimensi Tangible (Berwujud)}

Dimensi tangible berkaitan erat dengan penampilan fisik dari fasilitas, perlengkapan, dan sumber daya manusia layanan. Dengan kata lain, kenyamanan tempat pelayanan bagi pelanggan maupun petugas (Front Office) dapat memberikan kesan baik. Lebih lanjut, dimensi tangible dalam pelayanan akademik berbasis one stop service di front office TU FE UNNES dijelaskan sebagai berikut.

a. Penampilan Petugas

Penampilan petugas bagian Front Office dalam melakukan layanan kepada mahasiswa FE UNNES sudah baik dan rapi, sudah menggunakan pakaian rapi dan sopan 
layaknya seorang resepsionis. Didukung dengan hasil wawancara dengan para informan berikut.

"Pakaian/seragamnya itu menyesuaikan dengan Staf Front Office, yang hari senin menggunakan hitam putih tetapi kami menggunakan putih-putih berjas seperti kalau kita disekolah, untuk hari rabu dan kamis memakai baju batik dan hari jumat memakai pakaian olahraga..." (P.F.D)

“... Penampilannya sudah bagus. Dia menyesuaikan jadi kalo senin kita Dosen Tendik pakai putih biasanya dia juga menggunakannya ditambahi dengan blazer, terutama kalau misalnya ada kegiatan kegiatan di Fakultas pasti dia suruh pakai yang resmi kaya gitu." (W.D)

"Kalau untuk penampilan ya jelas, kita menyesuaikan dengan tendik FE dan harus rapi intinya rapi serta sopan. Kalau senin pakai baju putih, selanjutnya batik ada hari-hari yang kita pakai blazer hari rabu selain itu batik terus hari jum'atnya itu pakainya olahraga nanti olahraga kalau ada acara resmi ya kita ganti baju habis olahraga." (F.D)

"Sudah rapi, terus ya mencerminkan seorang Front Office dan resepsionis gitu yah. Mereka itu kayaknya menyesuaikan dari FE sendiri kan, biasanya kalau hari senin putih rapi biasanya pakai jas.” (P.L.PE)

"Penampilan petugasnya menurut saya petugasnya disitu rapi sih mas. Menggunakan pakaian yang tertutup dan baju berkerah dan kalau aturan dari fakultas sendiri kan senin menggunakan putih dan kamis batik sudah sesuai." (P.L.MAN)

"Penampilannya sudah baik sudah rapi melayaninya juga ramah, rapi dari segi pakaian ya kan kalau dari pakaian sudah sesuai prosedur maksudnya kalau melayani tidak benerin jilbab atau apa gitu.” (P.L.Ak)

Berdasarkan dengan hasil wawancara, pengamatan dan dokumentasi tersebut dapat terlihat bahwa penampilan petugas bagian Front Office dalam melakukan layanan kepada mahasiswa FE UNNES sudah baik, rapi, sesuai dengan tendik FE. Hari senin menggunakan pakaian hitam putih, hari selasa batik, hari rabu blazer, kamis batik, dan hari jumat menggunakan pakaian olahraga.

b. Tempat Pelayanan

Tempat kerja merupakan salah satu faktor pendukung kelancaraan pekerjaan. Sebagaimana proses pelayanan untuk tetap menjaga kualitas dari pelayanan itu sendiri maka harus menciptakan tempat yang nyaman untuk proses tersebut. Dilihat dari tempat layanan, bagian Front Office FE UNNES sudah cukup bagus. Tata ruang dan fasilitas yang disediakan juga sudah cukup baik. Ketika masuk Gedung FE UNNES L1, lokasinya 
baik, sudah bagus, karena disitu langsung tertuju pada bagian Front Office yang siap untuk melayani tentang akademik. Hal ini sesuai dengan hasil wawancara di bawah ini:

"Sudah yah, sekarang tempatnya di depan yah, sudah gitu selalu ada. Sebelumnya itukan kaya kita loket gitu terus kadang-kadang bapaknya gak ada kalau sekarang itu selalau ada stand by gitu. Mudah sih kan itu didepan banget ya mas jadi Mahasiswa gak masuk masuk gitu.” (P.L.PE)

"Tempatnya mudah untuk pelayanan. Soalnya didepan juga jadi kita gak perlu muter-muter nyari tempatnya kaya tanya satpam pun sudah bener-bener ini udah strategis bagian depan itu. Menurut aku kalau buat proses layanan memadai sih soalnya misalnya ditunggupun depannya ada sofa." (P.L.MAN)

"Kalau dari proses layanan sudah memadai. Cuman saya mau renovasi sedikit. Jadi, antara Front Office sama TU mau dikasih pintu sambungan yang masuk karena kan kalau kita bongkar itu kan gak mungkin.” (W.D)

"Diletakkan dimanapun tidak masalah yang penting dekat akses Tata Usahanya karena itu juga memengaruhi kecepatan layanan itu sendiri.” (P.L.MAN)

"Tempatnya itu lokasinya itu sangat strategis di depan FE di Loby FE jadi itu Mahasiswa mudah menjangkau. Kendala pertama terkait dengan tempat kurang luas, jadi peralatan terbatas berpengaruh kepada fasilitas yang kita gunakan, atau peralatan perlengkapan untuk menunjang terbatas seperti filling cabinet harusnya kita membutuhkan 2 tapi hanya memuat 1 . Kalau untuk tempatnya kan kita gak bisa ngotak atik kan soalnya mejanya itu permanen gak bisa diobahobah. Terus habis kita menyiasati dengan menggunakan snelhecter. Tapi berhubung kurang luas itu jadi tidak bisa hanya muat 1 dan dikhususkan untuk legalisir yang tebal-tebal itu kan dokumennya, kemudian solusinya kita adalah menggunakan snelhecter dan Box File. Fasilitas sudah cukup lengkap memadai, kekurangannya itu cuman yang filling cabinet itu gara-gara kurang lengkap, telepon ada, faximile ada, jadi kita kadang juga mengirim lewat fax ke pihak luar atau pihak luar ngirim fax lewat fax ke FE gitu. Sejauh ini sudah memenuhi untuk standar pelayanan" (F.D)

"Ada telepon antar ruang, ada komputer, ya mungkin kita tambah mungkin lokernya (Filling cabinet) yang bisa membedakan layanan apa saja supaya tidak terselip kemana-mana." (K.TU)

Terlihat dari hasil wawancara, tempat pelayanan di bagian Front Office FE UNNES sudah sangat strategis, berada di depan dan berdekatan dengan bagian Tata Usaha sebagai Back Office. Tempat Front Office untuk melakukan pelayanan juga sudah memadai, namun akan direnovasi kembali karena tempat tersebut masih terlalu sempit untuk dapat menambah fasilitas penunjang layanan tersebut dan akan dibuatkan pintu yang terhubung langsung ke bagian Back Office supaya pelayanan lebih efektif dan efisien. 
c. Kedisiplinan Petugas

Kedisiplinan petugas Front Office dimulai dari jadwal pelayanan atau jam kerja tersebut sudah cukup baik namun perlu ditingkat kembali. Hal itu terlihat dari kesiapan para petugas untuk melayani mahasiswa. Seperti yang disampaikan oleh para informan berikut.

"Petugas disini ini disiplin sesuai jam kerja. Jadi jam kerja kita jam 7-4 sore, istirahatnya jam 12-1 siang. Kalau untuk kembali lagi setelah istirahat setelah makan itu manusiawi mas makannya diluar paling lama paling 1 jam.” (K.TU)

"Kalau selama pengamatan saya mereka bagus pulang juga sesuai jam kerja. Nah kalo presensi, kalau kami pegawai yang sudah jelas tetap kan sudah pakai online yah kalau mereka belum." (K.B.A)

"Menurut saya istilahnya walaupun ada jam istirahatnya ataupun yang lain itu sudah disiplin, kalau saya kesana petugas Front Officenya ada." (P.L.MAN)

"Agak kurang ya mas, kalau untuk jam 1 kan harusnya sudah masuk tapi kadang kalau aku mau ambil surat atau apa belum ada petugasnya yang jaga. Jam 1 lebih 11 juga petugasnya belum ada kadang kala gitu tapi seringnya gitu kalau aku mau ngambil belum ada." (P.L.EP)

"Ya kalau dibilang disiplin mungkin udah, pernah saya kesini istirahat (jam 121), saya kesini jam 1 petugasnya belum ada belum siap kali yah, saya pernah kesini jam 1 petugasnya tidak ada. Menurut saya sudah bagus sih, misal seperti surat observasi biasanya kan emang 2-3 hari itu pasti 2-3 udah jadi. Ya kalau jam kerja sudah disiplin sih kemarin saya juga pernah jam segitu jam istirahat kesana terus petugasnya bilang maaf yah nanti istirahat dulu. Kalau tidak salah ngurus KRS.” (P.L.PE)

"Kalau saya lihatkan baru 2 minggu saya PKL disini untuk petugasnya sudah disiplin mas dan pernah kami pada jam istirahat sekitar jam 1 kurang itu melayani Mahasiswa padahal itukan masih jam istirahat karena pelayanan dimulai jam 1 tapi kami tetap melayaninya. Terus kadang dari Staf Front Office itu ada yang jam 1 sudah pelayanan kadang juga jam 1 lebih.” (P.F.D)

"Petugasnya sudah disiplin ya mas menurut saya itu, sesuai dengan prosedurnya mungkin.” (P.L.Ak)

Dengan demikian, kedisiplinan petugas Front Office dalam melakukan pelayanan kepada mahasiswa FE UNNES dengan jam kerja harus diperhatikan baik-baik karena sudah banyak mahasiswa yang menunggu untuk melakukan pelayanan di bagian Front Office. Jam masuk setelah istirahat menjadi perhatian untuk ditingkatkan karena banyak mahasiswa yang sudah menunggu petugas tersebut. 


\section{Dimensi Reliabilitas}

a. Kecermatan Petugas

Petugas Front Office harus memiliki kompetensi sesuai dengan bidang pelayanan kepada mahasiswa untuk dapat melakukan pelayanan dengan cermat demi meningkatkan pelayanan. Apalagi dengan bagian Front Office ini yang semua layanan dipusatkan di bagian tersebut serta sebagai pusat informasi maka petugas harus memiliki kompetensi dan menguasai bidang administrasi perkantoran karena akan berpengaruh terhadap kualitas pelayanan yang diberikan kepada mahasiswa FE UNNES. Hasil wawancara dari informan mendukung pernyataan tersebut, menyatakan bahwa:

"Sudah cermat yah mas, saya belum pernah salah dalam menerima pelayanan disini. Pelayanannya sudah seperti yang saya harapkan karena tidak ada kesalahan. Soalnya juga saya yakin kalau sudah bekerja disitu pasti mereka punya kompetensi. Kompetensi yang menguasai bidang itu kalau sejauh ini saya belum menemukan kaya capnya miring atau apa dan minta ini keluarnya lain juga belum pernah" (P.L.MAN).

"Sudah cermat, dan sudah sesuai dengan pesananannya" (P.L.Ak).

"Sudah cermat, dari kemarin saya ngurus surat-surat disini belum pernah saya menemukan kesalahan terhadap apa yang saya minta dan yang saya minta itu benar mas" (P.L.PE).

Petugasnya inikan tidak resmi, artinya tidak seleksi kita itu. Kita itu menyerahkan ke Dosen AP. Untuk mencarikan Petugas Front Officenya. Jadi kita tidak melakukan seleksi sementara. Kedepan mungkin kita akan melakukan seleksi kalau mbaknya ini sudah lulus diganti terus sudah tidak ada lagi program magang di AP ya kita mau tidak mau harus mencari sendiri. Kalau belum dapet ijin dari Kemenristek ya dari Tenaga yang ada dimanfaatkan. Jadi kalau kontraknya itu satu tahun biasanya dan iya bisa diperpanjang itukan ada kalau sini itu namanya tenaga kontrak. Itu kan ada penilainya yang dikontrak. Kita posisikan sebagai Aslab jadi ini belum formal bener" (K.TU).

Berdasarkan hasil wawancara, observsi, dan dokumentasi tersebut terlihat bahwa petugas Front Office harus memiliki kompetensi yang sesuai dengan bidang pelayanan kepada mahasiswa untuk dapat melakukan pelayanan yang cermat demi meningkatkan pelayanan. Apalagi dengan bagian Front Office ini yang semua layanan dipusatkan dibagian tersebut serta sebagai pusat informasi maka petugas harus memiliki kompetensi dan menguasai bidang administrasi perkantoran karena akan berpengaruh terhadap kualitas pelayanan yang diberikan kepada mahasiswa FE UNNES. Oleh karena itu, tingkat kecermatan petugas Front Office sudah cermat dan detail. Hal ini ditandai dengan 
belum ada komplain hanya saja sedikit terkendala waktu penyelesaian yang dilakukan oleh Back Office.

b. Proses Layanan

Pelayanan akademik mahasiswa di UNNES telah menggunakan satu sistem yaitu Sistem Informasi Surat Dinas (SIRADI). Dengan adanya sistem tersebut semua kebutuhan mahasiswa terkait dengan akademik maupun perkuliahan mereka terdapat pada SIRADI tersebut. Setelah mahasiswa memesan kebutuhan mereka pada sistem SIRADI tersebut setelah itu akan keluar nomor agenda sebagai bukti pemesanan mereka. Selanjutnya, pada Bagian Front Office sudah tersedia form untuk menuliskan nomor agenda setelah mereka dapat dari pemesanan sebelumnya melalui SIRADI. Tujuan dari nomor agenda pada SIRADI yaitu untuk memudahkan mahasiswa dalam meminta jenis layanan. Jenis pelayanan yang dilakukkan pada bagian Front Office FE UNNES mencakup kepentingan akademik mahasiswa FE UNNES seperti yang disampaikan oleh petugas Front Office, menyatakan bahwa:

"Layanan terkait dengan kepentingan Mahasiswa. Contohnya untuk pembuatan surat-menyurat, KRS, KHS gitu khusus bidang akademik yang bisa dilayani ya kami layani kalau gak bisa ya kami arahkan ke Back Office. Jadi ada percetakan, pemesanan KRS, KHS, surat observasi mata kuliah, skripsi, penelitian skripsi, terus aktif kuliah, beasiswa, kehilangan KTM, dan lain sebagainya. Kalau kaya surat yang lain yang tidak ada di Siradi itu kami arahkan untuk menemui Pak Sriyono ataupun Bu Rohmah yang lebih mengetahui. Jadi kita hanya terbatas yang terdapat di Siradi aja gitu." (F.D)

Pelayanan yang dilakukan oleh bagian Front Office sudah sesuai dengan apa yang diharapkan oleh mahasiswa FE UNNES namun belum sepenuhnya optimal. Hasil penelitian menyatakan bahwa:

"Sudah, sejauh ini petugasnya belum terjadi kesalahan jadi sesuai dengan apa yang saya harapkan." (P.L.PE)

"Kalau misalkan sesuai yang diharapkan mungkin kurang. Lagi-lagi diwaktunya kurang sesuai dengan waktu yang sudah dijanjikan seperti itu.” [(P.L.EP)

"Iya mas, karena saya belum pernah mendapatkan kesalahan dalam layanan ini jadi sesuai dengan harapan.” (P.L.MAN)

"Sudah mas, meskipun kemarin ada sedikit kesalahan yang entah kemana surat tersebut, tetapi akhirnya surat tersebut dapat segera diurus." [(P.L.Ak)

Berdasarkan hasil wawancara, pengamatan dan dokumentasi yang telah dilakukan mengenai proses pelayanan di bagian Front Office FE UNNES sudah sesuai dengan harapan mahasiswa, karena proses layanan mudah dan lebih terstruktur pelayanannya. 
Dibagian Front Office sudah tersedia form untuk memudahkan mahasiswa dalam meminta jenis layanan. Pelayanan difokuskan melalui bagian Front Office yang hanya menerima permintaan layanan dan selanjutnya untuk pengerjaan atau proses layanan tersebut dilakukan oleh bagian Back Office. Back Office menerima form dari petugas Front Office yang kemudian mengecek nomor agenda tersebut di SIRADI, setelah itu di cetak kemudian diserahkan kepada Kasubag Akademik untuk dicek dan setelah surat tersebut sudah benar kemudian dikasih paraf yang kemudian dilanjutkan dengan minta tanda tangan kepada yang bersangkutan setelah itu kemudian Back Office/Front Office memberi cap stempel, kemudian diserahkan kembali kepada bagian Front Office untuk diambil oleh mahasiswa.

\section{Dimensi Tanggapan}

a. Sikap Petugas

Petugas Front Office memiliki keharusan untuk menyambut dan merespon mahasiswa yang datang. Pengguna layanan akan merasa dihargai oleh petugas Front Office saat petugas dapat memberikan respon yang baik. Merespon mahasiswa dapat menimbulkan pengaruh positif bagi kualitas pelayanan di bagian Front Office FE UNNES. Petugas merespon dan tanggap dengan para mahasiswa yang ingin mendapatkan layanan ini dibuktikan ketika mahasiswa sudah selesai mendapatkan pelayanan. Sikap petugas Front Office dalam melayani mahasiswa FE UNNES sudah sesuai yang diharapkan oleh mahasiswa sebagaimana disampaikan dalam hasil wawancara bahwa sikap petugas Front Office dalam melayani mahasiswa FE UNNES yang meminta pelayanan harus selalu direspon mahasiswa dengan baik, selalu tersenyum, menyapa mahasiswa yang datang untuk meminta pelayanan. Masukan dari pimpinan FE yang menghimbau petugas Front Office untuk selalu senyum, sapa, dan menawarkan bantuan kepada mahasiswa yang datang sebagai pembelajaran untuk selalu profesional dalam melakukan pelayanan kepada mahasiswa.

b. Layanan Cepat

Petugas Front Office dalam melayani mahasiswa FE dengan cepat, hal tersebut dilakukan dengan sesegera mungkin karena untuk menjaga citra lembaga tersendiri. FE UNNES yang menginginkan pelayanan akademik bagi mahasiswa mereka dengan optimal selanjutkan melakukan pembaruan dengan terobosan layanan satu pintu melalui bagian Front Office. Terlihat bahwa petugas Front Office dalam melayani dan merespon mahasiswa yang datang untuk meminta pelayanan dapat dilayani dengan cepat. Dengan 
kata lain, demi meningkatkan dan menjaga kualitas pelayanan kepada mahasiswa maka petugas Front Office selalu berupaya melayani degan cepat dikarenakan banyak mahasiswa yang meminta pelayanan supaya pelayanan tersebut tetap berjalan dengan lancar. Kecepatan faktor pelayanan juga tergantung dengan Back Office dalam prosesnya serta keberadaan pimpinan di tempat untuk penyelesaian proses layanan tersebut.

c. Layanan Tepat

Keakuratan atau ketepatan dokumen permintaaan pelayanan menjadi tolak ukur dari kemampuan petugas Front Office dalam memberikan pelayanan kepada mahasiswa FE UNNES. Hasil penelitian menunjukkan bahwa petugas Front Office dalam melakukan pelayanan kepada mahasiswa FE UNNES dengan teliti. Hal ini ditandai dengan penyimpanan dokumen pelayanan yang sudah dikelola dengan baik, seperti dokumen legalisir yang disimpan pada filling cabinet, surat-surat, KRS dan sebagainya disimpan pada file box yang juga sudah dibedakan per jurusan untuk dapat memudahkan dalam proses pengambilan kepada mahasiswa. Demi menciptakan pelayanan berkualitas harus selalu mewujudkan pelayanan prima untuk setiap pelaynan. Ketepatan dokumen pelayanan yang diminta mahasiswa sudah sesuai.

d. Layanan Tepat Waktu

Pelayanan akademik yang terselenggara di bagian Front Office FE UNNES selalu dilakukan dengan cepat, supaya tidak ada permintaan dan berkas yang menumpuk. Selain itu, pemberian layanan tepat waktu dimaksudkan sebagai upaya mewujudkan pelayanan prima. Hasil penelitian membuktikan bahwa pelayanan mahasiswa di bagian Front Office dilakukan dengan cepat supaya tidak ada perimintaan/berkas yang menumpuk. Upaya penyelesaian tepat waktu tersebut juga untuk mewujudkan pelayanan prima. Proses layanan akademik mahasiswa dilaksanakan dengan tepat waktu terus diupayakan untuk menjaga kualitas layanan. Pimpinan fakultas juga merespon dengan cepat apabila ada dokumen yang diminta, serta tidak ada kegiatan di luar kota demi menjaga kualitas pelayanan.

\section{Dimensi Jaminan}

Dimensi jaminan berkaitan dengan pengetahuan dan kesopanan karyawan serta kemampuan mereka dalam menumbuh kembangkan rasa percaya (trust) dan keyakinan pelanggan (confidence). Hal ini penting mengingat mahasiswa mengharapkan proses layanan yang cepat. Pengukuran dimensi jaminan (assurance) dalam layanan akademik berbasis one stop service di bagian Front Office FE UNNES dapat diukur melalui indikator 
jaminan tepat waktu. Jaminan tepat waktu dalam proses layanan akademik bagian Front Office FE UNNES itu sudah diberikan akan tetapi tidak semua layanan dapat selesai tepat waktu setelah dijanjikan tersebut. Didukung oleh hasil wawancara dengan informan yang mengatakan bahwa:

"Kalau jaminan waktunya, pernah kita ngurus KHS itu ya kan emang biasanya 1 hari jadi, nah kemarin dibilangin 2-3 hari jadi, tapi ternyata gak jadi. Dan akhirnya saya gak jadi observasi karena surat ini. Intinya gimana yah kan tergantung juga dari birokratnya kan mengenai tanda tangan ya kadang sesuai ekspektasi kadang enggak.” (P.L.PE).

Indikator jaminan tepat waktu dalam melayani mahasiswa menunjukkan bahwa petugas mampu memberikan jaminan estimasi waktu selesainya pelayanan tersebut. Pengurusan surat yang memerlukan tanda tangan pimpinan bisa sampai 2-3 hari dan juga tergantung keberadaan di tempat. Selanjutnya, cetak KHS dan KRS 1 hari, legalisir 2-3 hari. Namun estimasi waktu yang telah diberikan oleh petugas Front Office di awal tersebut masih ditemukan pelayanan yang selesainya melebihi waktu yang telah diberikan faktor yang memengaruhinya yaitu perjalanan dinas pimpinan fakultas, petugas Back Office ada kegiatan mendadak, ada gangguan di sistem atau laman SIRADI.

\section{Dimensi Empati}

Dimensi empati (empathy) diartikan sebagai bentuk perusahaan dalam memberikan perhatian secara personal kepada para pelanggan dan memiliki jam operasi yang nyaman. Pengukuran dimensi jaminan (assurance), dalam layanan akademik berbasis one stop service di bagian Front Office FE UNNES dapat diukur melalui indikator sebagai berikut:

a. Perhatian Petugas

Petugas Front Office FE UNNES dalam memberikan layanan akademik bagi mahasiswa dengan mengoptimalkan pelayanan akademik sesuai dengan permintaan mahasiswa. Setiap mahasiswa yang datang selalu dilayaninya dengan baik, seperti yang disampaikan oleh para informan bahwa:

"Menurut saya iya mas, karena petugasnya kadang-kadang sedang melakukan sesuatu tapi pas saya nanya itu dijawab mbaknya" (P.L.Ak).

"Biasanyan itukan mbak-mbaknya ngurus administrasi ya mas dan kalau saya datangpun langsung ditanya ada keperluan apa yah mas. Jadi beliau meninggalkan tugasnya sementara" (P.L.MAN).

"Iya selama ini sudah mendahulukan, karena pada saat ingin meminta pelayanan petugasnya itu sedang mengerjakan sesuatu langsung mengutamakan kita" (P.L.PE). 
Berdasarkan hasil wawancara tersebut terlihat bahwa petugas Front Office FE UNNES dalam melayani mahasiswa yang datang untuk melakukan pelayanan, petugas mengutamakan mahasiswa yang datang dikarenakan petugas Front Office tidak melakukan proses layanan hanya menerima permintaan dari mahasiswa. Akan tetapi petugas dalam kedisiplinan jam masuk kembali setelah istirahat perlu diperhatikan karena banyak mahasiswa yang ingin melakukan pelayanan di jam 1 namun petugasnya sendiri belum berada di tempat.

b. Pelayanan Ramah dan Sopan Santun

Petugas Front Office sebagai wajah instansi dalam melakukan pelayanan kepada mahasiswa dengan ramah dan sopan santun demi mewujudkan citra positif bagi instansi tersebut, seperti yang disampaikan oleh informan bahwa:

"Sudah ramah, kalau saya melihat Mbaknya itu langsung senyum dan sopan baik banget pokoknya mas" (P.L.EP).

"Iya mas mbak-mbaknya sangat ramah kepada saya dan merespon dengan baik ketika saya nanya sesuatu" (P.L.Ak)

"Iya mas petugasnya sangat ramah kepada saya dan responnya baik sopan santun gitu” (P.L.MAN)

Dengan demikian, dapat disimpulkan bahwa petugas Front Office FE UNNES dalam melayani mahasiswa bersikap dengan baik dan merespon dengan ramah serta menanyakan keperluan mahasiswa saat datang ke bagian Front Office tersebut. Namun masih dijumpai mahasiswa yang dilayaninya kurang ramah dan sopan. Hal ini menunjukkan bahwa petugas Front Office FE UNNES harus selau menyapa mahasiswa yang datang, menjaga sikap, dan melayaninya dengan ramah demi menjaga kualitas pelayanan.

\section{Hambatan dalam proses layanan akademik Front Desk FE UNNES}

Pelayanan akademik pasti mengalami hambatan atau kendala dalam penyelenggaraan pelayanan akademik, di bagian Front Office FE UNNES terdapat hambatan yaitu fasilitas pelayanan penunjang masih kurang dan tempat layanan seperti telah disampaikan oleh petugas Front Office dan mahasiswa. Petugas Front Office menyampaikan dalam proses layanan yang dialakukan terdapat hambatan yaitu

"Hambatannya itu fasilitasnya, peralatan dan perlengkapannya itu, gara-gara itu kurang luas kita kurang leluasa, kita tidak bisa menambah filling cabinet. Tapi sejauh ini tidak ada hambatan yang begitu mengganggu proses layanan. Soalnya kan tidak ada filling cabinet juga kan kita bisa menyiasati dengan snelhecter itu terus kalau ada penumpukkan ya kita pindahkan jadi file inaktif itu aja. Sejauh 
ini baik-baik aja tidak ada hambatan yang sangat berarti. Paling ya itu membuat mahasiswa sabar untuk menunngu kan ada mahasiswa yang ngeyel gitu" (F.D).

Proses layanan bagian Front Office masih terdapat beberapa mahasiswa mengalami hambatan dalam pelayanan, seperti berikut ini:

"Mungkin kalau ramai, kan mbaknya cuman 2 tuh biasanya mungkin agak kesulitan yah tempatnya kaya gitu juga dari kitanya itu juga susah untuk ngedului ya tinggal kesabarannya kita aja. Kalau dari masalah Front Office-nya itu gak ada. Kendalanya, kadang di sistemnya sih, aku kan masih baru disini jadi belum tahu alurnya jadi harus nanya dulu ke Front Office, jadi sekalian ngisi disana" (P.L.MAN).

"Kalau kendala dalam proses layanan sih mungkin kendala dari saya pribadi yah saya salah dalam mengisi online tadi jadi salah pribadi sih kalau pegawai sih minim kesalahan. Jadi yang saya lihat sih kesalahan banyak di mahasiswanya ketika melakukan pemesanan di online seperti surat ijin. Contohnya saya pernah meminta stempel sertifikat nah itu saya minta hari ini tapi itu dilayani besokbesoknya padahal menjanjikan besok udah jadi pada saat saya kesana belum jadi lantas ketika itu saya yang nyetempel sendiri jadi mungkin ada kelalaian dari petugas mungkin lupa. Ya mungkin dari janji yang sudah dijanjikan tersebut mungkin sedikit over time yah mas kelebihan waktu" (P.L.PE).

Dengan demikian, kendala atau hambatan pelayanan akademik yang ada di bagian Front Office FE UNNES adalah pertama terkait dengan tempat dan fasilitas pelayanan yang masih kurang memadai, terkait dengan sistem di SIRADI, dan terkait dengan waktu dalam proses pelayanan tersebut.

\section{Upaya yang dilakukan oleh FE UNNES}

Hambatan yang terjadi dalam pelayanan akademik di bagian Front Office FE UNNES harus segera diatasi dengan cepat dan tepat, supaya penyelenggaraan pelayanan akademik dapat berjalan secara optimal. Pihak Fakutltas melakukan upaya perbaikan dalam mengatasi hambatan disampaikan oleh Petugas Front Office dalam proses layanan akademik terkait dengan tempat dan fasilitas pelayanan, seperti yang disampaikan oleh Wakil Dekan II dan petugas Front Office bahwa:

“... Saya mau renovasi sedikit jadi pintu antara Front Office sama TU mau dikasih pintu sambungan yang masuk karena kan kalau kita bongkar itukan gak mungkin terus ada kaya kalau di rumah tangga ada uang langsung direhab. Itukan harus mesti prosedural jadi Insya Allah mungkin tahun depan sudah kami rencanakan dalam arti antara Front Office dan TU itu ada pintu bukaannya sehingga kalau selama inikan mungkin harus dianter muter, biar jadi efisien" (W.D).

Sementara dalam merespon keluhan dari mahasiswa petugas Front Office FE UNNES menyatakan bahwa: 
"Kalau kaya kertas terlipat itu saya kurang tau gak ada yang bilang kesaya. Kalau dibelakang bilang gimana gak tau tapi kalau bilang langsung gak ada. Kita sempet ada survei atau angket kepuasan itu rata-rata menjawab puas, hanya beberapa yang kurang puas. Langsung saya tanyakan kenapa kurang puas mbak buat evaluasi kekita juga kan itu katanya gara-gara itu tidak cepat selesai gitu tapi Alhamdulillah 90\% lah puas. Jadi proses pembuatannya itu di Back Office bukan dari Front Office gitu pokoknya kita saling melengkapi. Terus kadang ada kendala juga pada sistem SIRADI di Back Office sejauh ini hanya itu gara-gara lama. Kemarin sempet error itu sistem SIRADI terus banyak keluhan-keluhan nah itu lama. Paling ya itu membuat Mahasiswa sabar untuk menunngu kan ada Mahasiswa yang ngeyel gitu" (F.D).

Oleh karena itu, untuk mengatasi hambatan dalam penyelenggaran pelayanan akademik di bagian Front Office FE UNNES yaitu dilakukan dengan berkala seperti penyediaan ATK atau fasilitas berkala, memperbaiki tempat pelayanan, dan memberikan informasi mengenai sistem SIRADI untuk diisinya secara hati-hati karena melalui sistem.

\section{Pembahasan Hasil Penelitian}

Pelayanan merupakan tindakan yang menawarkan bantuan kepada pihak lain dan bersifat tidak berwujud serta tidak menimbulkan kepemilikan apapun. Berkaitan dengan pelayanan perguruan tinggi, kualitas layanan akademik dapat dinilai dengan membandingkan antara layanan yang dirasakan pelanggan atau stakeholders dengan kualitas layanan akademik yang diharapkan pelanggan atau stakeholders. Pada dasarnya, mahasiswa sangat senang dan puas apabila mereka memperoleh pelayanan akademik yang terbaik, dimana pelayanan tersebut sudah diperbarui dengan penambahan bagian front office yang diharapkan melayaninya dengan profesional karena merupakan kesan tersendiri dan utama. Profesionalisme petugas front office terkait dengan berbagai aspek seperti keterampilan, pengalaman kerja, tata nilai, prosedur kerja, pengkoordinasian, dan penghargaan.

Prosedur layanan akademik surat menyurat di bagian front office FE UNNES dilakukan dengan mahasiswa mengisi keperluan urusan di sistem SIRADI, setelah selesai mengisi kemudian keluar nomor agenda. Selanjutnya, nomor agenda tersebut kemudian mahasiswa datang ke bagian Front Office untuk mengisi form yang tersedia. Setelah mengisi form kemudian diserahkan kembali kebagian Front Office dan dari bagian Front Office tersebut nanti akan diserahkan kebagian Back Office (Tata Usaha Fakultas) untuk diproses.

Setelah dokumen diterima bagian front office kemudian diberi stempel dan dilakukan penyimpanan sesuai dengan "nama" dan "jurusan" yang bersangkutan supaya memudahkan dalam proses penemuan atau penyerahan dokumen tersebut kepada mahasiswa. Selanjutnya, estimasi waktu penyelesaian sekitar 2-3 hari dan juga tergantung dari keberadaan pimpinan 
yang menandatangani dokumen tersebut. Kemudian, alur layanan akademik dengan keperluan cetak KRS dan Kartu Hasil Studi (KRS) dimulai dengan mahasiswa mengisi form, kemudian diserahkan ke Front Office, dan dari bagian Front Office diserahkan ke bagian Back Office, dicetak di bagian Back Office setelah itu diberikan kembali kebagian Front Office dan simpan sesuai dengan "nama" dan "jurusan".

Pengelolaan universitas hendaknya berfokus pada layanan, informasi dan fasilitas untuk memenuhi kepuasan mahasiswa, dan kualitas layanan adalah paling penting dari semuanya. Selain itu, penyelenggaraan pelayanan akademik mahasiswa Fakultas Ekonomi sudah menggunakan pelayanan satu pintu (One Stop Service), sasaran penyelenggaraan pelayanan terpadu satu pintu seperti pada Peraturan Menteri Dalam Negeri Republik Indonesia Nomor 138 Tahun 2017 Pasal 3 yaitu terwujudnya pelayanan yang cepat, mudah, transparan, pasti, sederhana, terjangkau, profesional, berintegritas, dan meningkatkan hak untuk mendapatkan pelayanan. Pelayanan satu pintu tersebut dimulai setelah penambahan bagian Front Office di Tata Usaha FE UNNES. Pelayanan mahasiswa di Tata Usaha FE UNNES sebelumnya untuk semua layanan dilakukan di bagian Tata Usaha (yang sekarang sebagai Back Office) menggunakan loket. Proses pelayanan tersebut semuanya dilakukan oleh bagian Tata Usaha dari pemesanan layanan sampai dengan pengambilan semuanya dilakukan di bagian tersebut. Setelah penambahan bagian Front Office pelayanan tersebut kemudian difokuskan kepada bagian Front Office. Bagian Front Office FE UNNES ditugaskan untuk menerima dan menyerahkan pelayanan akademik mahasiswa. Sedangkan untuk bagian TU FE UNNES menjadi bagian Back Office yang bertugas mengolah pelayanan dari bagian Front Office sampai dengan tanda tangan yang kemudian diserahkan kembali ke bagian Front Office untuk dapat diserahkan kepada mahasiswa.

\section{Dimensi Tangible (Berwujud)}

Berdasarkan hasil penelitian dimensi tangible ditentukan oleh indikator-indikator yaitu penampilan petugas Front Office dalam memberikan pelayanan, kenyamanan sarana dan tempat pelayanan memadai untuk pelayanan, kedisiplinan petugas Front Office dalam memberikan pelayanan kepada para mahasiswa. Pada dimensi tangible ini menunjukkan hal yang baik, meski tidak sepenting dengan petugas pemberi layanan. Apabila dipersiapkan dengan baik ibarat buku sampulnya langsung kelihatan bagus dan menarik, sehingga mampu membuat mahasiswa dan stakeholder puas terhadap layanan akademik bagian Front Office FE UNNES. Penelitian terdahulu menjelaskan bahwa kualitas pelayanan memiliki hubungan yang kuat dengan kepuasan pelanggan sehingga pelayanan harus dikelola untuk 
meningkatkan kepuasan pelanggan (Dawi, Jusoh, Streimikis, \& Mardani, 2018; Kurniawan, Rosanto, \& Shinta, 2019). Hasil penelitian ini konsisten dengan Desiyanti, Sudja, \& Budi Martini (2018) yang menemukan bahwa service quality have positive and significant effect to customer satisfaction and customer delight. Artinya semakin baik kualitas pelayanan yang diberikan oleh organisasi, kepuasan pelanggan akan meningkat. Sebaliknya kualitas pelayanan yang buruk dapat menurunkan kepuasan pelanggan. Hasil penelitian yang sama juga ditemukan oleh Khairusy \& Febriani (2020) bahwa kualitas produk dan jasa berpengaruh sebesar 55,7\% terhadap kepuasan konsumen.

Layanan akademik Front Office FE UNNES pada dimensi tangible bisa dikatakan baik karena dari semua indikator yang digunakan dalam penelitian ini hampir semuanya baik antara lain penampilan petugas Front Office FE UNNES. Tapi pada indikator kedisiplinan petugas Front Office dan sarana atau fasilitas pelayanan ini cukup baik. Hal ini dikarenakan petugas Front Office tidak disiplin waktu terutama ketika jam istirahat. Seharusnya setelah jam istirahat selesai petugas Font Office sudah kembali ke tempat kerja. Dari segi sarana masih belum lengkap seperti filling cabinet masih kurang untuk menyimpan berkas serta ruang yang kurang memadai menyebabkan tidak memungkinkannnya untuk penambahan fasilitas serta tempat layanan Bagian Front Office yang terlalu sempit untuk proses layanan. Seirama dengan Parasuraman, Berry, \& Zeithaml (1988) yang menyatakan bahwa dimensi berwujud (tangible) meliputi fasilitas fisik, perlengkapan dan peralatan yang digunakan, serta penampilan petugasnya yang dapat diandalkan keadaan lingkungan sekitarnya merupakan bukti nyata yang diberikan oleh penyedia layanan.

\section{Dimensi Reliability (Kehandalan)}

Dimensi ini menunjukkan pada kemampuan pemberi layanan dalam melayani pelanggan sesuai yang dijanjikan secara tepat, cermat, sesuai standar. Kemampuan kehandalan pegawai dalam memberikan pelayanan sangat membantu mahasiswa FE UNNES. Pengukuran yang dilakukan dalam pelayanan akademik bagian Front Office FE UNNES menggunakan beberapa indikator diantaranya adalah kecermatan petugas dalam melayani mahasiswa, kompetensi petugas, pelayanan sudah sesuai dengan harapan atau belum. Namun, pelaksanaan layanan akademik pada indikator kecermatan petugas ditemukan masih belum sesuai harapan mahasiswa, contohnya pengisian form di bagian Front Office tersebut masih dijumpai kekurangan data mahasiswa seperti NIM yang mengakibatkan tidak bisa untuk dicetak permintaan tersebut. 
Proses layanan mahasiswa yang akan menilai bagaimana kinerja dan kemampuan dari petugas Front Office dalam memberikan atau melaksanakan proses pelayanan akademik. Kompetensi atau kemampuan petugas Front Office FE UNNES sudah sesuai karena latar belakang dari petugas Front Office tersebut adalah mahasiswa administrasi perkantoran. Dimana kemampuan petugas dapat memengaruhi keberhasilan pelayanan. FE UNNES menerapkan beberapa syarat kompetensi diantaranya seperti yang disampaikan oleh beberapa informan utama yaitu berasal jurusan administrasi perkantoran, karena pada jurusan ini terdapat Mata Kuliah Praktik Perkantoran sehingga mahasiswa memiliki pengalaman terkait cara memberikan pelayanan yang baik. Kemudian dari segi Innerbeauty, bahasa komunikasi, gesture, dan penampilan.

Hal tersebut juga didukung dari hasil penelitian Fikri (2016); Hidayat, Mulyana, \& Effendy (2018); Mensah \& Mensah (2018); Rahmat Yuliawan (2017); Rinala, Yudana, \& Natajaya (2013) menunjukkan bahwa kepuasan mahasiswa dipengaruhi secara positif oleh kehandalan. Artinya, persepsi mahasiswa yang semakin baik terhadap kehandalan, maka mahasiswa akan cenderung memiliki kepuasan terhadap pelayanan. Hal ini sesuai dengan teori SERVQUAL dalam Tjiptono (2017) menyebutkan bahwa keandalan atau reliabilitas berhubungan dengan bagaimana perusahaan mampu untuk menyampaikan pelayanan seperti yang telah dijanjikan sejak pertama kali.

\section{Dimensi Responsiveness (Tanggapan)}

Pelayanan akademik bagian Front Office FE UNNES sudah menerapkan dimensi responsiveness beserta indikator. Pada dimensi responsiveness ini pelayanan sudah sesuai yang diharapkan mahasiswa yaitu petugas Front Office yang siap dan merespon keperluan mahasiswa dengan cepat. Yuliagni (2017) menyatakan kesiapan diartikan sebagai kesediaan dalam merespon dan bereaksi. Penilaian kualitas layanan akademik yang sudah berjalan sesuai harapan mahasiswa dalam dimensi ini antara lain sikap petugas Front Office dalam memberikan layanan, kecepatan proses pelayanan, ketepatan proses layanan, ketepatan waktu proses layanan dan keluhan dalam proses layanan.

Ringkasan analisis kualitatif yang telah dilakukan terhadap dimensi responsiveness dapat dijelaskan sebagai berikut: hasil penelitian menunjukkan bahwa layanan akademik di bagian Front Office FE UNNES pada dimensi responsiveness juga cukup baik karena dari empat indikator yang ada dalam dimensi ini menunjukkan ada tiga dimensi positif. Tiga hal positif dalam dimensi ini yaitu petugas dalam melayani dan menyapa mahasiswa kurang begitu baik, pelayanannya juga sudah cukup cepat seperti yang disampaikan oleh informan 
juga tergantung dari Back Office, selama ini belum terdapat kesalahan dalam melayani mahasiswa seperti kesalahan pengambilan berkas dan lain-lain, artinya pelayanan yang diberikan sudah tepat. Meskipun demikian, lembaga masih perlu meningkatkan pelayanannya demi menjaga citra atau image.

Seirama dengan Teori Parasuraman et al. (1988) dan Tjiptono (2017) yang menyampaikan bahwa daya tanggap (responsiveness) berkaitan dengan kesediaan pemberi layanan dalam membantu dan merespon segala permintaan pelanggan dengan segera. Sejalan dengan hasil penelitian sebelumnya yang menyatakan bahwa ada pengaruh responsiveness terhadap kepuasan mahasiswa (Astuti, Mangungsong, \& Purnaningrum, 2014; Gultom, Ginting, \& Sembiring, 2014; Mariska \& Hati, 2015; Ratnah \& Muljadi, 2018; Rudi Aryanto, 2017; Susanto, 2014). Hal ini berarti semakin baik pelaksanaan pelayanan dengan dimensi responsiveness maka kepuasan mahasiswa juga semakin meningkat.

\section{Dimensi Assurance (Jaminan)}

Jaminan berkaitan dengan bagaimana pemberi layanan dapat menjamin ketepatan waktu, legalitas, dan jaminan mendapatkan fasilitas seperti karyawan tetap di bagian Front Office FE UNNES. Dalam penelitian Rahareng \& Relawan (2017), perguruan tinggi hendaknya mengusahakan untuk melakukan pengelolaan sistem mutu layanan dan administrasi untuk menghasilkan sistem layanan dan administrasi yang transparan dan tepat waktu. Dimensi assurance dapat dilihat dan diukur dengan jaminan tepat waktu, legalitas, dan jaminan mendapatkan fasilitas seperti karyawan FE UNNES.

Rangkaian analisis pada indikator assurance (jaminan) dapat dijelaskan sebagai berikut; kualitas pelayanan akademik dibagian Front Office FE UNNES. Penelitian ini menunjukkan bahwa indikator yang dalam dimensi assurance cukup baik. Hal ini terlihat dari beberapa indikator yang hasilnya masih belum cukup baik untuk para mahasiswa. Seperti jaminan tepat waktu yang mana belum semua pelayanan dapat diselesaikan tepat waktu. Dimensi assurance ini berisi tentang memberikan kepastian kepada mahasiswa FE. Hal yang menyebabkan baiknya dimensi ini adalah bahwa petugas Front Office FE UNNES mendapatkan jaminan legalitas dari Fakultas Ekonomi berupa SK Dekan meskipun masih mengatasnamakan Asisten Laboratorium, serta petugas dapat menggunakan fasilitas seperti halnya yang diberikan kepada karyawan Fakultas Ekonomi UNNES.

Hal tersebut sesuai dengan Teori Parasuraman, Berry, \& Zeithaml (1988) menyatakan bahwa jaminan berkaitan dengan pemahaman dan kesopanan pemberi layanan serta kemampuan mereka dalam menumbuh kembangkan rasa percaya (trust) dan keyakinan 
kepada pelanggan. Hasil penelitian ini juga didukung dengan hasil penelitian Marlius (2018); Putra \& Yasa (2015); Rusdin (2017), dimensi assurance berpengaruh signifikan terhadap kepuasan mahasiswa pada website akademik STIE. Hasil penelitian tersebut konsisten dengan hasil penelitian Hendri \& Robyardi (2019); Juhana \& Mulyawan (2015); Mulyawan \& Rinawati (2016) yang menyatakan mengenai pengaruh kepastian (assurance) menunjukkan hasil positif dan signifikan terhadap tinggi rendahnya kepuasan mahasiswa di STMIK Mardira Indonesia Bandung.

\section{Dimensi Empathy (Empati)}

Empati merupakan perhatian yang diberikan petugas Front Office kepada mahasiswa di Fakultas Ekonomi. Kesediaan mendahulukan kepentingan mahasiswa FE, bersikap ramah, sopan dan santun terhadap mahasiswa yang meminta layanan, serta mengikuti kegiatan sebagaimana yang dilakukan oleh karyawan di Fakultas Ekonomi. Hal ini senada dengan penelitian Lubis (2013) menyatakan bahwa menurut mahasiswa, masalah yang sering terjadi berkaitan dengan dimensi empati yaitu kurangnya keramahan pegawai saat memberikan pelayanan bagi mahasiswa.

Rangkaian analisis kualitatif pada dimensi empathy dapat dijelaskan melalui indikator dalam dimensi ini yang mana semuanya cukup baik. Tapi ada yang perlu digarisbawahi karena adanya diskriminasi terkait dengan sapaan petugas yang belum semua mahasiswa disapa ketika hendak meminta pelayanan. Petugas front office biasa memberikan sapaan kepada mahasiswa yang memiliki kedekatan dengan petugas tersebut. Hal ini tentu saja akan menimbulkan pandangan negatif bagi mahasiswa yang lain, karena diskriminasi yang dilakukan tersebut.

Hal tersebut menunjukkan bahwa seharunya mahasiswa diperlakukan sama sehingga berdampak pada meningkatnya kepuasan mahasiswa. Didukung oleh Teori Parasuraman et al. (1988) menyatakan bahwa empati diartikan sebagai bentuk perusahaan dalam memberikan perhatian secara personal kepada para pelanggan. Hampir sama dengan penelitian yang dilakukan oleh Rahmat Yuliawan (2017), pelayanan empati berkontribusi secara signifikan terhadap kepuasan mahasiswa di Universitas Airlangga. Hasil penelitian tersebut konsisten dengan hasil penelitian Girsang \& Saragih (2018); Huwaida, Rofi'i, \& Imelda (2018); Nugroho, Cahyono, \& Suryawirawan (2018); Wahyuningsih, Graha, \& Sarwoko (2010); Yunaida (2018) yang menyatakan bahwa dimensi empati berpengaruh signifikan terhadap kepuasan mahasiswa. 


\section{KESIMPULAN}

Berdasarkan hasil penelitian dan pembahasan yang telah diuraikan, maka dapat diketahui bahwa layanan akademik di bagian Front Office FE UNNES mencakup (1) Dimensi Tangible (Berwujud) di bagian Front Office FE UNNES terdiri dari penampilan petugas Front Office FE UNNES, kenyamanan sarana prasarana dan tempat pelayanan, output/luaran, serta kedisiplinan petugas Front Office dalam melakukan pelayanan kepada mahasiswa. (2) Dimensi Reliability (Kehandalan) di bagian Front Office FE UNNES terdiri dari kecermatan petugas, kompetensi petugas, pelayanan Front Office sesuai harapan mahasiswa. (3) Dimensi Responsiveness (Daya Tanggap) di bagian Front Office FE UNNES terdiri dari harapan mahasiswa, kecepatan proses layanan, ketepatan, ketepatan waktu layanan, dan keluhan dalam proses layanan dibagian Front Office FE. (4) Dimensi Assurance (Jaminan) di bagian Front Office FE UNNES yaitu jaminan tepat waktu dalam penyelesaian proses layanan kepada mahasiswa. (5) Dimensi Empathy (Empati) di bagian Front Office FE UNNES terdiri dari mendahulukan kepentingan mahasiswa, sikap petugas yang ramah dan sopan santun, serta petugas mengikuti kegiatan karyawan di Fakultas Ekonomi. Dari lima dimensi tersebut, penyelenggaraan pelayanan akademik juga mengalami kendala seperti kurang memadainya tempat dan fasilitas pelayanan. Ditambah lagi, sistem persuratan menggunakan SIRADI masih sering error sehingga menghambat pekerjaan mahasiswa dan berdampak pada ketidakpuasan pelayanan akademik. Untuk mengatasi kendala tersebut, instansi berupaya untuk memperbaiki tempat pelayanan dan memberikan informasi mengenai sistem SIRADI.

Penelitian ini juga menunjukkan beberapa implikasi dari perspektif teoritis yaitu hasil penelitian berkontribusi menambah penelitian empiris tentang pentingnya memahami layanan akademik, karena layanan akademik dengan mengimplementasikan Teori SERVQUAL memberikan dampak pada peningkatan kepuasan pelanggan. Selain itu, penelitian ini juga memberikan implikasi yang bermanfaat bagi penyedia layanan akademik yaitu institusi pendidikan tinggi bahwa layanan akademik berpengaruh terhadap kualitas layanan. Selanjutnya, temuan juga membuktikan bahwa penting bagi institusi pendidikan tinggi untuk fokus meningkatkan strategi kualitas layanan. Temuan ini memiliki keterbatasan yang dapat digunakan untuk perbaikan lebih lanjut. Fokus penelitian ini menggunakan sampel dari populasi mahasiswa Fakultas Ekonomi UNNES, sehingga untuk menggeneralisasi temuan ini diperlukan penelitian komparatif. Oleh karena itu, penelitian ini harus ditindaklanjuti di masa depan untuk menginvestigasi komponen-komponen yang mendukung dalam kualitas layanan akademik. 


\section{DAFTAR PUSTAKA}

Agustini, S. (2020). Analisis Indeks Kepuasan Pelanggan Terhadap Layanan Perencanaan, Anggaran, dan Pelaporan. Efisiensi : Kajian Ilmu Administrasi, 17(1), 1-14. Retrieved from https://journal.uny.ac.id/index.php/efisiensi/article/view/30435.

Arisandy, M. (2015). Pengaruh Keterampilan dan Pengalaman Kerja terhadap Pengembangan Karir Pegawai pada Dinas Pendidikan Kabupaten Donggala. E-Jurnal Katalogis, 3(8), 149-156. Retrieved from http://jurnal.untad.ac.id/jurnal/index.php/Katalogis/article/view/6406.

Astuti, A. B., Mangungsong, R. R. D., \& Purnaningrum, W. D. (2014). Pengaruh Kualitas Pelayanan Akademik terhadap kepuasan Mahasiswa di jurusan Terapi Wicara Poltekkes Kemenkes Surakarta. Jurnal Terpadu Ilmu Kesehatan, 3(2), 106-214. Retrieved from http://jurnal.poltekkes-solo.ac.id/index.php/Int/article/view/98.

Chrisyanti, I. (2011). Manajemen Perkantoran. Jakarta: PT. Prestasi Pustakaraya.

Dawi, N. M., Jusoh, A., Streimikis, J., \& Mardani, A. (2018). The Influence of service Quality on customer Satisfaction and customer Behavioral Intentions by Moderating Role of switching Barriers in satellite Pay TV Market. Economics and Sociology, 11(4), 198-218. https://doi.org/10.14254/2071-789X.2018/11-4/13.

Desiyanti, N. L., Sudja, I. N., \& Budi Martini, L. K. (2018). Effect of Service Quality on customer Satisfaction, Customer Delight and customer Loyalty (Study on LPD Desa Adat Sembung and LPD Desa Adat Seseh). International Journal of Contemporary Research and Review, 9(03), 20660-20668. https://doi.org/10.15520/ijcrr/2018/9/03/483.

Fikri, S. dkk. (2016). Pengaruh Kualitas Pelayanan Terhadap Kepuasan dan loyalitas Mahasiswa (Studi pada Mahasiswa Strata I Fakultas Ilmu Sosial dan Ilmu Politik Universitas Merdeka Malang). Jurnal Bisnis Dan Manajemen, 3(1), 122. Retrieved from http://jurnal.unmer.ac.id/index.php/jbm/article/viewFile/80/21.

Ghofur, M. A. (2013). Kredibilitas dan otentisitas Guru Kewirausahaan terhadap Karakter Kewirausahaan Siswa SMK Negeri di Surabaya. Jurnal Ekonomi Pendidikan Dan Kewirausahaan, 1(1), 39-52. Retrieved from https://doi.org/10.26740/jepk.V1n1.P39-52.

Gie, T. L. (2009). Administrasi Perkantoran Modern. Yogyakarta: Liberty.

Girsang, R. M., \& Saragih, L. (2018). Analisa Kualitas Pelayanan terhadap Kepuasan Mahasiswa Menggunakan Laboratorium Komputer Universitas Simalungun. Jesya (Jurnal Ekonomi \& Ekonomi Syariah), 2(1), 136-144. https://doi.org/10.36778/jesya.v2i1.44.

Gultom, D. K., Ginting, P., \& Sembiring, B. K. (2014). Pengaruh bauran Pemasaran Jasa dan Kualitas Pelayanan terhadap Mahasiswa Program Studi Manajemen Fakultas Ekonomi Universitas Muhammadiyah Sumatera Utara. Manajemen Dan Bisnis, 14(01), 21-33. https://doi.org/https://doi.org/10.30596/jimb.v14i01.113

Hendri, E., \& Robyardi, E. (2019). Kajian Empiris Kualitas Layanan terhadap Loyalitas yang Dimediasi oleh Kepuasan Mahasiswa (Studi kasus pada UPT Perpustakaan 
Universitas PGRI Palembang). Jurnal Media Wahana Ekonomika, 15(4), 1. https://doi.org/10.31851/jmwe.v15i4.3049.

Hidayat, L., Mulyana, M., \& Effendy, M. (2018). Membangun Kepuasan Mahasiswa Pengguna Laboratorium Komputer. JAS-PT Jurnal Analisis Sistem Pendidikan Tinggi, 1(2), 93. https://doi.org/10.36339/jaspt.v1i2.87.

Huwaida, H., Rofi'i, \& Imelda, S. (2018). Pengaruh Kualitas Pelayanan Pendidikan terhadap Kepuasan Mahasiswa di Jurusan Administrasi Bisnis Politeknik Negeri Banjarmasin. Jurnal INTEKNA, 18(2), 100-110. Retrieved from https://ejurnal.poliban.ac.id/index.php/intekna/article/view/689.

Ismiyati. (2011). Faktor Daya Tarik dan Kinerja Pelayanan Menurut Persepsi Mahasiswa : Studi FE Unnes. Dinamika Pendidikan, 6(2), 170-187. https://doi.org/10.15294/dp.v6i2.5110.

Juhana, D., \& Mulyawan, A. (2015). Pengaruh Kualitas Layanan Jasa Pendidikan terhadap Kepuasan Mahasiswa di STMIK Mardira Indonesia Bandung. Jurnal Ekonomi, Bisnis \& Entrepreneurship Vol., 9(1), 1-15. Retrieved from https://jurnal.stiepas.ac.id/index.php/jebe/article/view/106/190.

Khairusy, M. A., \& Febriani, R. (2020). Pengaruh Kualitas Produk dan Kualitas Pelayanan Terhadap Kepuasan Pelanggan (Survey pada Pelanggan KFC Store Merdeka Bandung). Jurnal Manajemen Dan Kewirausahaan, 1-12. Retrieved from http://ejournal.lppm-unbaja.ac.id/index.php/jmb/article/view/811.

Kurniawan, A., Rosanto, O., \& Shinta, M. R. (2019). Pengaruh Kualitas Pelayanan terhadap Kepuasan Pasien BPJS pada RSUD Budhi Asih Jakarta Timur. At-Tadbir: Jurnal Ilmiah Manajemen, 3(1), 1-10. https://doi.org/10.31602/atd.v2i1.1191.

Lubis, A. (2013). Pengaruh Kualitas Pelayanan Pendidikan terhadap Kepuasan dan Loyalitas pada Mahasiswa Fakultas Ekonomi Universitas Medan Area Medan. Jurnal Konsep Bisnis Dan Manajemen, 1(1), 29-36.

Mariska, L., \& Hati, S. W. (2015). Pengaruh Kualitas Pelayanan Akademik terhadap Kepuasan Mahasiswa di Politeknik Negeri Matam. Jurnal Akuntansi, EKonomi, Dan Manajemen Bisnis, 3(1), 1-9. Retrieved from https://jurnal.polibatam.ac.id/index.php/JAEMB/article/view/178.

Marlius, D. (2018). Pengaruh Dimensi Kualitas Pelayanan Website Akademik terhadap Kepuasan Mahasiswa pada STIE KBP. Jurnal Ipteks Terapan, 12(2), 116. https://doi.org/10.22216/jit.2018.v12i2.633.

Mensah, I., \& Mensah, R. D. (2018). Effects of Service Quality and Customer Satisfaction on Repurchase Intention in Restaurants on University of Cape Coast Campus. Journal of Tourism, Heritage \& Services Marketing, 4(1), 27-36. https://doi.org/10.5281/zenodo.1247542.

Miles, M. B., \& Hubberman, A. H. (1994). Qualitative Data Analysis. Riverside County, CA: SAGE Publications.

Mulyawan, A., \& Rinawati. (2016). Pengaruh Kualitas Layanan Akademik terhadap 
Kepuasan Mahasiswa serta Implikasinya pada Loyalitas Mahasiswa (Studi pada Sekolah Tinggi Manajemen Informatika dan Komputer di Kota Bandung. Juranal Ekonomi, Bisnis \& Entrepreneurship, 10(2), 119-131. Retrieved from https://jurnal.stiepas.ac.id/index.php/jebe/article/view/9.

Mulyawan, A., \& Sidharta, I. (2013). Analisis Deskriptif Pemasaran Jasa di STMIK Mardira Indonesia Bandung. Jurnal Computech \& Bisnis, 7(1), 42-55. Retrieved from http://jurnal.stmik-mi.ac.id/index.php/jcb/article/view/100/0.

Nugroho, N. E., Cahyono, K. E., \& Suryawirawan, O. A. (2018). Pengaruh Kualitas Pelayanan Akademik terhadap Kepuasan Mahasiswa Sekolah Tinggi Ilmu Ekonomi Indonesia (STIESIA) Surabaya. Prosiding SENDI_U 2018, 552-558. Retrieved from https://www.unisbank.ac.id/ojs/index.php/sendi_u/article/view/6034.

Parasuraman, A., Berry, L. L., \& Zeithaml, A. V. (1988). Servqual: A Multiple Item Scale for Measuring Consumer Perceptions of Service Quality. Journal of Retailing, 64(1), 12-40. Retrieved from https://www.semanticscholar.org/paper/SERVQUAL\%3A-Amultiple-item-scale-for-measuring-of-ParasuramanZeithaml/d26a2423f00ca372b424a029ae22521299f00ede.

Putra, I. K. M., \& Yasa, N. K. (2015). Pengaruh Kualitas Pelayanan terhadap Kepuasan Mahasiswa, Citra, dan Positive Word of Mouth Politeknik Negeri Bali. Jurnal Bisnis Dan Kewirausahaan, 11(1), 46-58. Retrieved from http://ojs.pnb.ac.id/index.php/JBK/article/view/103.

Rahareng, V. J., \& Relawan, N. (2017). Pengaruh Kualitas Pelayanan Akademik terhadap Kepuasan Mahasiswa (Studi pada Mahasiswa Administrasi Bisnis Universitas Telkom). AdBispreneur, 2(2), 125-133. https://doi.org/10.24198/adbispreneur.v2i2.13164.

Ratnah, \& Muljadi. (2018). Pengaruh Tangible dan Responsiveness terhadap Kepuasan Wajib Pajak Kendaraan Bermotor pada Layanan Samsat Keliling Balaraja Kabupaten Tanggerang Banten. Jurnal Perilaku Dan Strategi Bisnis, 6(1), 37-46. https://doi.org/10.26486/jpsb.v6i1.

Rinala, I. N., Yudana, I. M., \& Natajaya, I. N. (2013). Pengaruh Kualitas Pelayanan Akademik terhadap Kepuasan dan Loyalitas Mahasiswa pada Sekolah Tinggi Pariwisata Nusa Dua Bali. Jurnal Administrasi Pendidikan, 4(1). https://doi.org/10.23887/japi.v4i1.916.

Rudi Aryanto. (2017). Pengaruh Kualitas Pelayanan Prodi Ekonomi Syariah dalam Penyelesaian Administrasi terhadap Kepuasan Mahasiswa dan Dampaknya terhadap Citra Prodi Ekonomi Syariah. I-Finance, 3(2), 9-14. https://doi.org/10.1016/j.jpainsymman.2017.04.009.

Rusdin. (2017). Pengaruh Kualitas Pelayanan terhadap Tingkat Kepuasan Pemustaka di UPT Perpustakaan Universitas Tadulako. Jurnal Katalogis, 5(11), 65-77. Retrieved from http://jurnal.untad.ac.id/jurnal/index.php/Katalogis/article/view/9760/7758.

Sholikah, M., \& Harsono, D. (2020). Tantangan Kualitas Layanan Berbasis Smart City pada Sektor Publik dan Privat The Challenges of Smart City- based Service Quality in Public and Private Sectors. Jurnal PKS, 19(2), 181-195. Retrieved from 
https://ejournal.kemsos.go.id/index.php/jpks/article/view/2075.

Sianipar, R. U. S. (2018). Pengaruh Kualitas Pelayanan Customer Relation terhadap Kepuasan Pengunjung di Mal SKA Pekanbaru. Jom Fisip, 5(1), 1-11. Retrieved from https://jom.unri.ac.id/index.php/JOMFSIP/article/view/16543.

Susanto, H. (2014). Pengaruh Layanan Akademik terhadap Kepuasan Mahasiswa Program Pascasarjana Universitas Terbuka pada Unit Program Belajar Jarak Jauh (UPBJJ) Mataram. Jurnal Pendidikan Terbuka Dan Jarak Jauh, 15(2), 1-98. https://doi.org/https://doi.org/10.33830/ptjj.v15i2.592.2014.

Tjiptono, F. (2017). Service Management-Mewujudkan Layanan Prima. Yogyakarta: Andi Offset.

Wahyuningsih, S., Graha, A. N., \& Sarwoko, E. (2010). Pengaruh Kualitas Pelayanan Terhadap Kepuasan Nasabah pada Bank Syariah Mandiri Cabang Malang. Jurnal Riset Mahasiswa Manajemen (JRMM), 5655. Retrieved from http://openjournal.unpam.ac.id/index.php/JFB/article/view/2266.

Yuliagni, L. (2017). Pengaruh Kesiapan Mahasiswa dan Kualitas Layanan Terhadap Kepuasan Mahasiswa pada Mahasiswa Pendidikan Akuntansi Angkatan 2015 Universitas Negeri Semarang. Universitas Negeri Semarang.

Yuliawan, R. (2017). Pengaruh Kualitas Pelayanan Pegawai Administrasi Akademik terhadap kepuasan mahasiswa Universitas Airlangga. Eksis: Jurnal Riset Ekonomi \& Bisnis, 12(2), 126-135. Retrieved from https://ejournal.stiedewantara.ac.id/index.php/001/article/view/102.

Yunaida, E. (2018). Pengaruh Kualitas Pelayanan Tenaga Kependidikan (Tendik) terhadap Kepuasan Mahasiswa Fakultas Ekonomi Universitas Samudra. Jurnal Manajemen Dan Keuangan, 7(1), 61-72. https://doi.org/10.33059/jmk.v7i1.758.

Zeithaml, V. A., \& Bitner, M. J. (2000). Services Marketing: Integrated Customer Focus Across the Firm, 2nd ed. New York: McGraw Hill.

\section{UCAPAN TERIMA KASIH}

Penulis mengucapkan terima kasih kepada redaksi dan staf Jurnal Efisiensi : Kajian Ilmu Administrasi yang telah memberikan kesempatan untuk penerbitan artikel ini. Selain itu, penulis juga menyampaikan terima kasih kepada semua pihak yang telah membantu pelaksanaan penelitian dan penerbitan artikel ini.

\section{PROFIL PENULIS}

Penulis pertama yaitu Umar Reza Saputra, S.Pd., lahir di Pemalang pada tanggal 10 Mei 1998. Menempuh pendidikan S1 Pendidikan Administrasi Perkantoran di UNNES lulus pada tahun 2020. Sedang menempuh pendidikan S2 Administrasi Publik di UNDIP angkatan 
Edisi Februari 2021, Volume 18, Nomor 1, ISSN 1412-1131, e-ISSN 2528-5750, Halaman 63-89

2020. Penulis kedua yaitu Ismiyati, S.Pd., M.Pd., merupakan dosen program studi Pendidikan Administrasi Perkantoran UNNES. Lahir di Magelang pada tanggal 2 September 1980. Menempuh pendidikan S1 Pendidikan Administrasi Perkantoran di UNNES dan lulus pada tahun 2004. Menempuh pendidikan S2 di UNY lulus pada tahun 2011. Saat ini, beliau sedang menempuh pendidikan jenjang S3 di Universitas Negeri Yogyakarta. Sementara itu, penulis ketiga yaitu Mar'atus Sholikah, lahir di Kudus pada tanggal 30 Desember 1995, menempuh pendidikan S1 Pendidikan Administrasi Perkantoran di UNNES dan lulus pada tahun 2018. Saat ini, ia sedang menempuh pendidikan jenjang S2 di Universitas Negeri Yogyakarta. 